\title{
Analysis of Chrome Tanned Leather Shavings Using Neutron Activation Analysis
}

\author{
S. S. ACHI ${ }^{*}$, D. J. ADEYEMO ${ }^{2}$, C. MAJU ${ }^{3}$ and J. TAGANG ${ }^{3}$ \\ ${ }^{1}$ Chemistry Department, Bingham University, Karu, Nasarawa State, Nigeria \\ ${ }^{2}$ Centre for Energy Research and Training, Ahmadu Bello University, Zaria, Nigeria \\ ${ }^{3}$ Federal College of Chemical and Leather Technology, Zaria, Nigeria \\ dr_achi03@yahoo.co.uk
}

Received 7 May 2011 / Accepted 16 May 2011

\begin{abstract}
Chrome tanned leather shavings collected from the federal college of chemical and leather technology (CHELTECH) Zaria, Nigeria's tannery were analyzed using centre for energy research and training (CERT), Zaria Nigeria's miniature neutron source reactor (MNSR). The main aim of this work was to determine the concentration of chromium and other constituents of the shavings. Chromium is known for its human toxicity which includes skin irritation, lung cancer, as well as Kidney, liver and gastric damages. The disposal of this waste without treatment will constitute a serious impact on the environment. The result obtained indicates that Chromium is as much as $1 \%$. The analyzed concentrations of As, Ba, Br, Co, Fe, La, Na, Sb, Sc, Sm and $\mathrm{Zn}$ in the sample are also presented. The results obtained were validated with the data obtained from the analysis of certified reference materials, IAEA-336 (Lichen) and IAEA 359 (Cabbage).
\end{abstract}

Keywords: Chrome tanned leather, Neutron activation analysis, Radionuclides

\section{Introduction}

Leather industry is one of the oldest cottage industries in Nigeria. Although tanning has been in existence for a long time, the problem of environmental pollution received serious consideration only in recent years. The pollutants from large tanneries have caused considerable damage to water courses, affecting drinking water supply, irrigation and aquatic life. It is realized that the untreated wastewater when allowed to stagnate, gives rise to odour nuisance, unsightly appearance creating ground and surface water pollution. Against this background, it is evident that pollution control is just unavoidable for the tanning industry to keep its environment clean and pollution free ${ }^{1}$.

When tanners shave the bottom sides of chrome-tanned hides to give them a uniform thickness, so-called chrome shavings end up as waste that must be hauled to landfills at a price. Wastes can be utilized to generate useful by-products.

The solid wastes coming from leather tanning with trivalent chrome salts (scraps leather and shavings) need a special attention due to the amount produced. One tonne of wet hide yields only $200 \mathrm{~kg}$ of leather but over $600 \mathrm{~kg}$ of solid waste or by-product ${ }^{2}$. It has been reported 
that about 600,000 of solid wastes each year worldwide are generated by the leather industry and approximately $40-50 \%$ of the hides are lose shavings and trimmings ${ }^{2}$. Chrome shavings constitute about $75 \%$ of the solid waste containing chromium in the tanning process.

Chromium exists in environment both as trivalent [Cr(III)] and hexavalent [Cr(VI)] forms of which the hexavalent form is 500 times more toxic than the trivalent one ${ }^{3}$. Human toxicity of $\mathrm{Cr}(\mathrm{VI})$ includes skin irritation to lung cancer, as well as kidney, liver and gastric damage $^{3}$.

Since chromium is known for its toxicity, the disposal of chrome shavings has been identified as a serious problem from the environmental point of view. Sastry et $a l^{4}$ developed two processes to offer an alternative and better solution for the disposal of chrome shavings. The first process is preparation of parchment-like membrane and the second process is related to development of leather-like material. The utilization of the chrome shavings in preparation of those two products not only reduces the environmental pollution but at the same time value added products can also be obtained.

Neutron activation analysis is a technique which, makes it possible to determine large number of elements in different types of matrices ${ }^{5}$. The Nigerian Research Reactor-1(NIRR-1) was used for the analysis. The NIRR-1 has a tank in pool structural configuration and a nominal thermal power rating of $31(\mathrm{~kW})$ with a built in clean cold core excess reactivity of $3.77 \mathrm{mk}$ measured during the on-site zero power and criticality experiments. Under these conditions the reactor can operate with the same fuel loading for over ten (10) years with a burn up of $<1 \%$. Neutron flux parameter of MNSRs are known to be stable, thus permitting the use of semi absolute Neutron Activation Analysis (NAA) $)^{5-9}$. NAA in its instrumental form, has some unique features which makes it attractive to use for routing analysis.

\section{Experimental}

Chrome shaving samples collected from the CHELTECH tannery to be analyzed were dried then ground into a powdered form of $125 \mu \mathrm{m}$ grain size. $250 \mathrm{mg}-300 \mathrm{mg}$ of the powdered samples were weighed.

NIRR-1 which is a low-power nuclear reactor with highly enriched uranium as fuel, light water as moderator and beryllium as reflector was used. The reactor's associated facility for radioactivity measurements are a gamma ray data acquisition system. It consists of a horizontal dip-stick High Purity Germanium (HPGs) detector with a relative efficiency of $10 \%$ at $1332.5 \mathrm{keV}$ gamma ray line, MAESTRO emulation software compatible with the ADCAM $^{\circledR}$ Multi-channel analyzer (MCA) card, associated electronic modules and a personal computer. For data processing gamma ray spectrum analysis, software WINSPAN $2004^{10}$ in addition to NAA calculations, perform peak analysis, remote control of MCA and other auxiliary functions such as efficiency calibration and nuclear data generation.

For irradiation, two schemes (long and short) were adopted based on the half-life of the product radionuclide. For elements leading to short-lived activation products the samples are each packed and sealed in $7 \mathrm{~cm}^{3}$ rabbit capsules and sent for irradiation in turn in an outer irradiation channel $\mathrm{B}_{4}$ where the neutron spectrum is "soft", the choice of the outer irradiation channel is to eliminate corrections, notably $\mathrm{Mg}$ in the presence of $\mathrm{P}$. This is due to the proximity of the inner channels of MNSRs to the core leading to relative higher ratio of fast-to-thermal neutron ${ }^{9}$.

For elements leading to long-lived activation products, samples wrapped in polyethylene films were then irradiated for $6 \mathrm{~h}$ in any of the small inner irradiation channels (i.e. $\mathrm{A}_{1}, \mathrm{~B}_{1}, \mathrm{~B}_{2}$ and $\mathrm{B}_{3}$ ) to take advantage of the maximum value of thermal neutron flux in the inner channels. 
Radioactivity measurements of induced radionuclides were performed by the PCbased gamma ray spectrometry set up. Following the short irradiation regime the first round of counting was performed for $10 \mathrm{~min}$ (i.e. S1) after a waiting time of 2-15 min. Samples were placed on a Plexi-glass sample holder designated "H2" which corresponds to source-detector geometry of $5 \mathrm{~cm}$. The second round of counting was also carried out for $10 \mathrm{~min}$. following the short irradiation regime (i.e. S2) after a waiting period of 3-4 h. Samples were counted on a Plexi-glass holder designated as "H1" corresponding to a source-detector geometry of $1 \mathrm{~cm}$. The neutron flux setting for the short irradiation of the sample was raised to $5 \times 10^{11} \mathrm{n} / \mathrm{cm} / \mathrm{s}$ sensitivities for analysis using procedures $\mathrm{S} 1$ and $\mathrm{S} 2$.

In the case of the long irradiation scheme, the first round of counting was carried out for 30 min following the long irradiation (i.e. L1) using the holder " $\mathrm{H} \mathrm{1}$ " after a waiting period counting was performed for 60 min (i.e. L2) after cooling time of 10-15 days. The samples were counted using the Plexi-glass holder "H1". The Choice of cooling time and sample detector geometry was such that detectors' dead time is controlled to be less than $10 \%$. For the biological material the certified reference material IAEA-359 (Cabbage) and IAEA-336 (Lichen) were chosen.

\section{Results and Discussion}

The irradiation and counting schemes together with the WINSPAN multi-element gamma-ray analysis software have been validated using the standard reference materials. Results printed in Table 1 give the routine irradiation and measuring regimes developed for NIRR-1 facilities. Table 2 gives comparison of certified values with our results in ppm or as indicated in \%for certified biological reference material, IAEA-336 (Lichen) and IAEA-359 (Cabbage). Table 3 gives nuclear data and limits of detection for the elements of interest using adopted experimental conditions. Table 4 gives the analytical results of INAA of chrome shavings.

Table 1. Routine irradiation and measuring regimes developed for NIRR-1 facilities

\begin{tabular}{llllll}
\hline $\begin{array}{l}\text { Neutron flux/irradiation } \\
\text { channel }\end{array}$ & Procedure & $T_{\text {irr }}$ & $T_{d}$ & $T_{c}$ & Activation products
\end{tabular}

$1 \times 10^{11} \mathrm{n} / \mathrm{cm}^{2} \mathrm{~s} /$ outer irradiation channels (B4, A2)

$5 \times 10^{11} \mathrm{n} / \mathrm{cm}^{2} \mathrm{~s} /$ inner irradiation channels (B1,B2,B3, L2 and A1)
S1 $2 \min 2-15 \min 10 \min$

$$
\begin{gathered}
{ }^{28} \mathrm{Al},{ }^{27} \mathrm{Mg},{ }^{38} \mathrm{C} 1,{ }^{49} \mathrm{Ca}, \\
{ }^{66} \mathrm{Cu},{ }^{51} \mathrm{Ti},{ }^{52} \mathrm{~V},{ }^{116 \mathrm{~m}} \mathrm{In}
\end{gathered}
$$

S2 $\quad 2 \min \quad 3-4 h \quad 10 \min$$$
{ }^{24} \mathrm{Na},{ }^{42} \mathrm{~K},{ }^{152 \mathrm{~m}} \mathrm{Dy},{ }^{56} \mathrm{Mn} \text {, }
$$

L1 6 h $\quad 4-5 d \quad 30$ min $\quad{ }^{239} \mathrm{~Np}(\mathrm{U}),{ }^{72} \mathrm{Ga},{ }^{122} \mathrm{Sb}$

$$
{ }^{46} \mathrm{Sc},{ }^{141} \mathrm{Ce},{ }^{60} \mathrm{Co},{ }^{51} \mathrm{Cr} \text {, }
$$

L2 6 h $\quad 10-15 d \quad 60 \mathrm{~min} \quad{ }^{134} \mathrm{Cs},{ }^{152} \mathrm{Eu},{ }^{182} \mathrm{~Tb},{ }^{175} \mathrm{Lu},{ }^{131} \mathrm{Ba}$, 
Table 2. Comparison of certified values with our results in ppm or as indicated in \% for the certified reference materials, IAEA-336 (Lichen) and IAEA 359 (Cabbage)

\begin{tabular}{|c|c|c|c|c|}
\hline & IAEA-336(Lichen) & \multirow{2}{*}{$(\mathrm{CV})$} & \multicolumn{2}{|l|}{ IAEA-339 (Cabbage) } \\
\hline Element & This work (TW) & & This Work (TW) & $(\mathrm{CV})$ \\
\hline $\mathrm{Al}$ & $709 \pm 35$ & $570-790$ & $175 \pm 13$ & $0.096-0.104$ \\
\hline As & BDL & $0.55-0.71$ & BDL & $10.5-11.5$ \\
\hline $\mathrm{Ba}$ & $11.0 \pm 1.3$ & $5.3-7.5$ & BDL & - \\
\hline $\mathrm{Br}$ & BDL & - & $8.0 \pm 3.0$ & $1.8-1.9$ \\
\hline Сa (\%) & BDL & $1.11-1.45$ & $1.97+0.12$ & - \\
\hline $\mathrm{Ce}$ & BDL & $0.24-0.34$ & BDL & - \\
\hline Co & BDL & $0.89-1.23$ & BDL & $1.24-1.36$ \\
\hline $\mathrm{Cr}$ & BDL & $0.097-0.123$ & BDL & - \\
\hline Cs & BDL & 144 & BDL & 78.6 \\
\hline $\mathrm{Cu}$ & BDL & $0.019-0.027$ & BDL & - \\
\hline $\mathrm{Eu}$ & BDL & $0.038-0.048$ & BDL & $0.014-0.15$ \\
\hline Fe, \% & BDL & $0.16-0.21$ & BDL & - \\
\hline $\mathrm{K}, \%$ & $0.66 \pm 0.04$ & $0.56-0.76$ & $3.3 \pm 0.4$ & $-0.21-0.22$ \\
\hline $\mathrm{La}$ & BDL & 0.004-0.009 & $0.27 \pm 0.05$ & 31.3-32.5 \\
\hline $\mathrm{Lu}$ & BDL & - & BDL & $567-601$ \\
\hline $\mathrm{La}$ & $61 \pm 2$ & $56-70$ & BDL & - \\
\hline Mg, \% & $317 \pm 16$ & $280-360$ & $29.4 \pm 0.8$ & - \\
\hline Mn & BDL & $1.54-1.98$ & $676 \pm 30$ & - \\
\hline $\mathrm{Na}$ & BDL & $0.063-0.083$ & BDL & - \\
\hline $\mathrm{Rb}$ & $0.16+0.03$ & $0.15-0.17$ & BDL & - \\
\hline SB & BD̄ & $0.092-0.12$ & BDL & - \\
\hline Sc & BDL & $0.012-0.016$ & BDL & - \\
\hline $\mathrm{Sm}$ & BDL & $0.12-0.16$ & BDL & - \\
\hline $\mathrm{Tb}$ & BDL & $1.25-1.69$ & BDL & - \\
\hline Th & BDL & 0.025-0.049 & BDL & - \\
\hline $\mathrm{V}$ & BDL & & BDL & - \\
\hline $\mathrm{Yb}$ & BDL & & BDL & - \\
\hline Zn & BDL & $27.0-33.8$ & BDL & - \\
\hline
\end{tabular}

$B D L$ - below detection limit

Table 3. Nuclear data and limits of detection for the elements of interest using adopted experimental conditions

\begin{tabular}{ccccc}
\hline Target isotope & $\begin{array}{c}\text { Product isotope } \\
\text { by }(\mathrm{n}, \gamma) \text { reaction }\end{array}$ & Half-life & $\begin{array}{c}\text { Gamma-energy } \\
\text { KeV }\end{array}$ & LOD, ppm \\
\hline${ }^{23} \mathrm{Na}$ & ${ }^{24} \mathrm{Na}$ & $14.96 \mathrm{~h}$ & 1368.60 & $40(\mathrm{~L} 1)$ \\
${ }^{26} \mathrm{Mg}$ & ${ }^{27} \mathrm{Mg}$ & $9.46 \mathrm{~min}$ & 1014.4 & $7250(\mathrm{~S} 1)$ \\
${ }^{27} \mathrm{Al}$ & ${ }^{28} \mathrm{Al}$ & $2.24 \mathrm{~min}$ & 1778.99 & $17(\mathrm{~S} 1)$ \\
${ }^{37} \mathrm{Cl}$ & ${ }^{38} \mathrm{Cl}$ & 37.24 & 1624.7 & $2900(\mathrm{~S} 1)$ \\
${ }^{41} \mathrm{~K}$ & ${ }^{42} \mathrm{~K}$ & $12.36 \mathrm{~h}$ & 1524.58 & $2400(\mathrm{~S} 2)$ \\
${ }^{45} \mathrm{Sc}$ & ${ }^{46} \mathrm{Sc}$ & $83.81 \mathrm{~d}$ & 889.28 & $0.2(\mathrm{~L} 2)$ \\
${ }^{48} \mathrm{Ca}$ & ${ }^{49} \mathrm{Ca}$ & $8.72 \mathrm{~min}$ & 3084.54 & $6600(\mathrm{~S} 1)$ \\
${ }^{50} \mathrm{Ti}$ & ${ }^{51} \mathrm{Ti}$ & $5.76 \mathrm{~min}$ & 329.08 & $2500(\mathrm{~S} 1)$ \\
\hline
\end{tabular}




\begin{tabular}{|c|c|c|c|c|}
\hline${ }^{50} \mathrm{Cr}$ & ${ }^{51} \mathrm{Cr}$ & $27.7 d$ & 320.98 & 23 (L2) \\
\hline${ }^{51} \mathrm{~V}$ & ${ }^{52} \mathrm{~V}$ & $3.75 \mathrm{~min}$ & 1434.08 & 15 (S1) \\
\hline${ }^{55} \mathrm{Mn}$ & ${ }^{56} \mathrm{Mn}$ & $2.58 \mathrm{~h}$ & 846.76 & 0.9 (S2) \\
\hline${ }^{58} \mathrm{Fe}$ & ${ }^{59} \mathrm{Fe}$ & $44.5 d$ & 1099.25 & 829 (L2) \\
\hline${ }^{59} \mathrm{Co}$ & ${ }^{60} \mathrm{Co}$ & $5.27 y$ & 1173.2 & 3.0 (L2) \\
\hline${ }^{65} \mathrm{Cu}$ & ${ }^{66} \mathrm{Cu}$ & $5.10 \mathrm{~min}$ & 1039.2 & 172 (S1) \\
\hline${ }^{64} \mathrm{Zn}$ & ${ }^{65} \mathrm{Zn}$ & $243.9 d$ & 1115.55 & 120 (L2) \\
\hline${ }^{71} \mathrm{Ga}$ & ${ }^{72} \mathrm{Ga}$ & $14.1 \mathrm{~h}$ & 834.1 & $1.0(\mathrm{~L} 1)$ \\
\hline${ }^{75}$ As & ${ }^{76}$ As & $26.32 \mathrm{~h}$ & 559.10 & 1.2 (L1) \\
\hline${ }^{81} \mathrm{Br}$ & ${ }^{82} \mathrm{Br}$ & $35.3 \mathrm{~h}$ & 776.5 & 3.0 (L1) \\
\hline${ }^{85} \mathrm{Rb}$ & ${ }^{86} \mathrm{Rb}$ & $18.8 d$ & 1076.6 & $3.0(\mathrm{~L} 2)$ \\
\hline${ }^{115} \mathrm{In}$ & ${ }^{116 \mathrm{~m}} \mathrm{In}$ & $54.15 \mathrm{~min}$ & 1097.3 & 0.5 (S1) \\
\hline${ }^{121} \mathrm{Sb}$ & ${ }^{122} \mathrm{Sb}$ & $64.8 \mathrm{~h}$ & 564.24 & 0.5 (L1) \\
\hline${ }^{133} \mathrm{Cs}$ & ${ }^{134} \mathrm{Cs}$ & $2.06 y$ & 795.85 & 1.7 (L2) \\
\hline${ }^{130} \mathrm{Ba}$ & ${ }^{131} \mathrm{Ba}$ & $11.8 \mathrm{~d}$ & 496.3 & 264 (L2) \\
\hline${ }^{139} \mathrm{La}$ & ${ }^{140} \mathrm{La}$ & $40.3 \mathrm{~h}$ & 1596.21 & 0.2 (L1) \\
\hline${ }^{140} \mathrm{Ce}$ & ${ }^{141} \mathrm{Ce}$ & $32.5 d$ & 145.44 & 14 (L2) \\
\hline${ }^{151} \mathrm{Eu}$ & ${ }^{152} \mathrm{Eu}$ & $13.3 y$ & 1408.5 & 0.6 (L2) \\
\hline${ }^{152} \mathrm{Sm}$ & ${ }^{153} \mathrm{Sm}$ & $46.27 \mathrm{~h}$ & 103.18 & 0.1 (L1) \\
\hline${ }^{159} \mathrm{~Tb}$ & ${ }^{160} \mathrm{~Tb}$ & 72.3d & 879.38 & 1.1 (L2) \\
\hline${ }^{164}$ Dy & ${ }^{165} \mathrm{Dy}$ & $2.33 \mathrm{~h}$ & 94.70 & 0.7 (S2) \\
\hline${ }^{174} \mathrm{Yb}$ & ${ }^{175} \mathrm{Yb}$ & 4.19d & 396.33 & 0.9 (L1) \\
\hline${ }^{176} \mathrm{Lu}$ & ${ }^{177} \mathrm{Lu}$ & $6.71 d$ & 208.36 & 0.1 (L2) \\
\hline${ }^{180} \mathrm{Hf}$ & ${ }^{181} \mathrm{Hf}$ & $42.4 d$ & 482.2 & 1.1 (L2) \\
\hline${ }^{181} \mathrm{Ta}$ & ${ }^{182} \mathrm{Ta}$ & $115 d$ & 1221.4 & $1.0(\mathrm{~L} 2)$ \\
\hline${ }^{197} \mathrm{Au}$ & ${ }^{198} \mathrm{Au}$ & $2.7 d$ & 411.8 & 0.02 (L1) \\
\hline${ }^{232} \mathrm{Th}$ & ${ }^{233} \mathrm{~Pa}$ & $27.00 \mathrm{~d}$ & 312.01 & 1.2 (L2) \\
\hline${ }^{238} \mathrm{U}$ & ${ }^{239} \mathrm{~Np}$ & $2.36 \mathrm{~d}$ & 277.60 & 1.5 (L1) \\
\hline
\end{tabular}

S1, S2, L1 and L2 represent Irradiation and counting schemes adopted for the respective element

The results in Table 4 show that chrome shavings are characterized by both benign and toxic substances. The elements of serious concern from the results obtained are the heavy metals. The data given in Table 4 shows that chromium contributes up to $1.0 \pm 0.03 \%$ of the quantum of the toxic substances in the chrome shavings samples analyzed. This shows that chrome shavings have high pollution load in excess of legal requirements for discharge into public refuse. The high pollution load observed is characteristic of tannery wastes ${ }^{11}$.

Turning to the question of clean production in regards to the results of this work (see Table 4), it is clear that leather production in the developing world generates waste that are characterized by heavy metals and other types of toxic substances. When compared with the Scottish Leather Group 2008 Environmental Report and Adidas 2009 Environmental Report on the use and disposal of leather and leather products waste, we find that the western world is well along the path towards cleaner leather making and waste management. This can be attributed to the fact that majority of the tanning industries in the developed world comply to the EU system for Registration, Evaluation and Authorization of Chemicals (REACH), the UK Landfill Allowances and Trading Scheme Regulations (LATS) and the US Environmental Protection Act 1990. The priorities in the developing world are different but rivers that will support life, agricultural land that will not grow plants, wells where the water has become non-potable, have become a powerful incentive to clean up the act. 
Table 4. Determined Elements and Concentrations of Chrome Shavings using NIRR-1

\begin{tabular}{|c|c|c|c|c|}
\hline Elements & $\begin{array}{l}\text { Product isotope by } \\
(\mathrm{n}, \gamma) \text { reaction }\end{array}$ & Half-life & $\begin{array}{c}\text { Gamma-energy } \\
\mathrm{KeV} \\
\end{array}$ & Concentrations \\
\hline $\mathrm{Al}$ & ${ }^{28} \mathrm{Al}$ & $2.24 \mathrm{~min}$ & 1778.99 & BDL \\
\hline As & ${ }^{76}$ As & $26.32 \mathrm{~h}$ & 559.10 & $2.1 \pm 0.3 \mathrm{ppm}$ \\
\hline $\mathrm{Ba}$ & ${ }^{131} \mathrm{Ba}$ & $11.8 \mathrm{~d}$ & 496.3 & $13.2 \pm 3.3$ ppm \\
\hline $\mathrm{Br}$ & ${ }^{82} \mathrm{Br}$ & $35.3 \mathrm{~h}$ & 776.5 & $10.4 \pm 0.5 \mathrm{ppm}$ \\
\hline $\mathrm{Ca}$ & ${ }^{49} \mathrm{Ca}$ & $8.72 \mathrm{~min}$ & 3084.54 & BDL \\
\hline Co & ${ }^{60} \mathrm{Co}$ & $5.27 \mathrm{y}$ & 1173.2 & $1.18 \pm 0.13 \mathrm{ppm}$ \\
\hline $\mathrm{Cr}$ & ${ }^{51} \mathrm{Cr}$ & $27.7 d$ & 320.98 & $1.0 \pm 0.03 \%$ \\
\hline Cs & ${ }^{134} \mathrm{Cs}$ & $2.06 y$ & 795.85 & BDL \\
\hline Dy & ${ }^{165}$ Dy & $2.33 \mathrm{~h}$ & 94.70 & BDL \\
\hline $\mathrm{Eu}$ & ${ }^{152} \mathrm{Eu}$ & $13.3 y$ & 1408.5 & BDL \\
\hline $\mathrm{Fe}$ & ${ }^{59} \mathrm{Fe}$ & $44.5 d$ & 1099.25 & $1.84 \pm 0.04 \%$ \\
\hline $\mathrm{Hf}$ & ${ }^{181} \mathrm{Hf}$ & $42.4 d$ & 482.2 & BDL \\
\hline $\mathrm{K}$ & ${ }^{42} \mathrm{~K}$ & $12.36 \mathrm{~h}$ & 1524.58 & BDL \\
\hline $\mathrm{La}$ & ${ }^{140} \mathrm{La}$ & $40.3 \mathrm{~h}$ & 1596.21 & $1.3 \pm 0.1 \mathrm{ppm}$ \\
\hline $\mathrm{Lu}$ & ${ }^{177} \mathrm{Lu}$ & $6.71 \mathrm{~d}$ & 208.36 & BDL \\
\hline $\mathrm{Mg}$ & ${ }^{27} \mathrm{Mg}$ & $9.46 \mathrm{~min}$ & 1014.4 & BDL \\
\hline Mn & ${ }^{56} \mathrm{Mn}$ & $2.58 \mathrm{~h}$ & 846.76 & BDL \\
\hline $\mathrm{Na}$ & ${ }^{24} \mathrm{Na}$ & $14.96 \mathrm{~h}$ & 1368.60 & $3.3 \pm 0.1 \mathrm{ppm}$ \\
\hline $\mathrm{Rb}$ & ${ }^{86} \mathrm{Rb}$ & $18.8 d$ & 1076.6 & BDL \\
\hline $\mathrm{Sb}$ & ${ }^{122} \mathrm{Sb}$ & $64.8 \mathrm{~h}$ & 564.24 & $1.0 \pm 0.1 \mathrm{ppm}$ \\
\hline Sc & ${ }^{46} \mathrm{Sc}$ & 83.81d & 889.28 & $0.5 \pm 0.02 \mathrm{ppm}$ \\
\hline $\mathrm{Sm}$ & ${ }^{153} \mathrm{Sm}$ & $46.27 \mathrm{~h}$ & 103.18 & $1.12 \pm 0.03 \mathrm{ppm}$ \\
\hline $\mathrm{Ta}$ & ${ }^{182} \mathrm{Ta}$ & $115 d$ & 1221.4 & BDL \\
\hline $\mathrm{Tb}$ & ${ }^{160} \mathrm{~Tb}$ & 72.3d & 879.38 & NA \\
\hline Th & ${ }^{233} \mathrm{~Pa}$ & $27.00 \mathrm{~d}$ & 312.01 & BDL \\
\hline $\mathrm{Ti}$ & ${ }^{51} \mathrm{Ti}$ & $5.76 \mathrm{~min}$ & 329.08 & BDL \\
\hline $\mathrm{U}$ & ${ }^{239} \mathrm{~Np}$ & 2.36d & 277.60 & BDL \\
\hline $\mathrm{V}$ & ${ }^{52} \mathrm{~V}$ & $3.75 \mathrm{~min}$ & 1434.08 & BDL \\
\hline $\mathrm{Yb}$ & ${ }^{175} \mathrm{Yb}$ & 4.19d & 396.33 & BDL \\
\hline $\mathrm{Zn}$ & ${ }^{65} \mathrm{Zn}$ & 243.9d & 1115.55 & $441 \pm 13$ ppm \\
\hline
\end{tabular}

BDL: Below Detection Limit, NA: Not Analysed

The results of this work are in agreement with a similar work conducted by $\mathrm{Mu}$, C. et al. ${ }^{12}$ on discharge of chromium-containing leather waste. We have found out that the concentration of the various elements (c.f. Tables 3 and 4) vary with their results data within relatively narrow ranges. In another related work it was reported that the concentration of chromium in chrome shavings varies from $1.8-4.0 \%$ as chrome (on dry solid weight basis) ${ }^{13}$ which is comparable with the percentage of chrome detected in our analysis. 
On the other hand, the data provided by Aslan ${ }^{14}$ showed a significant difference in the values of the concentration of the various elements detected in the present work. The concentration of the elements presented in Table 4 are higher than those published in Aslan'sdata. The results revealed that the principles for sustainable industrial practice set out in Agenda 21 of the 'Earth Submit' Rio Conference on waste management ${ }^{15}$ have not fully been adopted by the leather industry, particularly in the developing countries.

On close examination of the results of this work vis-a-vis the Nigerian Environmental standards for discharge of waste containing chromium ${ }^{16}$, we have found out that leather production in Nigeria generates waste that contain high concentration of hazardous substances. For example, the allowable minimum limit for disposal of chromium $\left(\mathrm{Cr}^{3+}\right.$ and $\mathrm{Cr}^{6+)}$ to sewers is $0.5 \mathrm{ppm}$ and $0.1 \mathrm{ppm}$, respectively and our results show that $\mathrm{Cr}$ in the chrome shavings analyzed is $10,000 \mathrm{ppm}$. It is important to point out here that the chief danger posed to the well-being of humans and other living things by indiscriminate disposal of hazardous wastes such as chrome shavings, even if stored in a non-aqueous environment like a land fill or buried underground in containers-lies in its potential to contaminate natural waters by migrating from its point of deposition by say, leaching ${ }^{17}$.

Other elements found in the chrome shavings as given in Tables 3 and 4 (Mg, Ca, etc.) can be attributed to the use of the salts of these elements for the basification of chrome tanned leathers. And the presence of other elements like $\mathrm{Ca}, \mathrm{Na}$, etc can be linked to the use of alkali in the pre-tanning treatment of hides/ skins. Based on the results of the analysis and the classification of wastes type outlined by Rahimifard ${ }^{18}$, chrome shavings can be categorized as $50 \%$ biodegradable waste.

\section{Conclusion}

The results have revealed the nature of chrome shavings generated from the tanning industry and have shown that the world environment is threatened by incessant pollution through disposal of leather wastes and other industrial wastes. In order to be able to save the environment from further degradation or increases in the accumulated amounts of hazardous waste in the future, some industrial operations should be designed in such a way that the "four Rs" (reduction, recycling, reuse and recovery) principle of waste management are employed in order to prevent any pollution from leaving a plant site.

\section{References}

1. Daryapurkar R A, Nandy T, Deshpane C V, Pathe P P and Kaul S N, Waste Management 17, Discovery Publishing House, New Delhi, 2005.

2. Rao J R, Thanikaivelan P Sreeram K J and Nair B U, Environ Sci Tech., 2002, 36, 1372-1376.

3. Tahiri S, Bouhria M, Albizane A, Messaoudi A, Azzi M, Alamos S, Younssi J and Mabrour J, Amer Leather Chem Assoc., 2004, 99, 16-25.

4. $\quad$ Sastry T P, Sehgal R K and Ramasami T, J Environ Sci Eng., 2005, 47(4), 250-5.

5. Munoz L, Gras N, Guzman C, Thieck M and Vanska L, J Radioanalytic Nuclear Chem., 1993, 167(1), 97-101.

6. Jonah S A, Balogun G I, Umar I M and Mayaki M C, J Radioanal Nucl Chem., 2005, 266(1), 83 - 88.

7. $\quad$ Akaho E H and Nyarko J B, Appl Radiat Isot., 2002, 57(2), 265-273.

8. Jonah, S A, Okunade, I O, Jimba, B W and Umar I M, Nucl Instr Methods A, 2001, 463, 321-323. 
9. Jonah S A, Umar I M, Oladipo M O A, Balogun G I and Adeyemo D J, Appl Radiation Isotopes, 2006, 64, 818-822.

10. Liyu W, NINSPAN, A multi-purpose Gamma-Ray Spectrum Analysis Software, CIAE Beijing, China, 2004.

11. Howie I, World Leather, 1995, 25-32.

12. Mu C, Lin W, Zhang M and Zhu Q, Waste Manage New York, 2003, 23, 835-843.

13. CLRI, Policy document, 2008 Feb Chennai, India. www.cpcb.nic.in/

14. Aslan A, Bulletin of the Environmental Contamination and Toxicology. Springer Science + Business Media, LLC, 2009.

15. Parson E A, Haas P M and Levy M A, Environ., 1992, 34(4), 12-15, 34-36.

16. FEPA, Federal Environmental Protection Agency (FEPA), Nigeria, 1991.

17. Baird C and Cann M, Environmental Chemistry, Fourth Printing, Freeman W H and Company, USA 2005.

18. Rahimifard S, Recycling of Footwear Products- A positioning paper, Centre for Sustainable Manufacturing and Reuse/Recycling Technologies, 2007. 